\title{
FIBRODYSPLASIA OSSIFICANS PROGRESSIVA
}

\author{
EDWARD R. TONHOLO-SILVA*, ELZA AQUIMI ADACHI**, MARIA SALETE TAFNER ${ }^{\star \star *,}$ \\ LUCIA YOSHINAGA****
}

SUMMARY - Fibrodysplasia (myositis) ossificans progressiva (FOP) is a rare autosomal dominant disorder in which there is a progressive ectopic ossification and skeletal malformation, mainly in the conective tissue of muscle. The diagnosis is based on the clinical findings and radiological demonstration of the skeletal malformations. We report a 5 year-old female case with FOP.

KEY-WORDS: fibrodysplasia ossificans progressiva, myositis, ossification.

\section{Fibrodisplasia ossificante progressiva}

RESUMO - Fibrodisplasia (miosite) ossificante progressiva (FOP)é doença rara, de herança autossômica dominante, na qual ocorre ossificaçāo ectópica progressiva e mal formação esquelética, principalmente no tecido conectivo dos músculos. O diagnóstico é baseado nos achados clínicos e demonstração radiológica das malformações esqueléticas. Relatamos o caso de uma menina de 5 anos de idade com FOP.

PALAVRAS-CHAVE: fibrodisplasia ossificante progressiva, miosite, ossificação.

Fibrodysplasia ossificans progressiva (FOP) is a rare autosomal dominant disorder in which there is a progressive ectopic ossification and skeletal malformation mainly in the connective tissue of muscles. The diagnosis is based on the clinical findings and radiological demonstration of the skeletal malformations. The management of the patients must be concentrated on the avoidance of exacerbating factors including trauma of the muscles, biopsies of the lumps, operations to excise ectopic bone, intramuscular injections and dental therapy. The treatment with disphosphonate dissodium etidronate (EHDP), an inhibitor of calcification, is given in an attemp to suppress calcification of new lesions. We report a case of FOP.

\section{CASE REPORT}

SSM, 5 year-old female child has presented at FMM Hospital de Clínicas complaing of knees and left shoulder movement restriction and pain in legs while walking. Frequently, she's fallen. She does not relate trauma history. Pregnancy was uncomplicated and delivery was normal, at home without medical assistance. She sustained her head at 2 months. Although she crawled at 7 months and walked at 1 year-old, she has not sit until present days. Talking began at the expected age. There have been no significant family illnesses reported. On the physical examination, she has presented flexion deformity of the knees, left shoulder painful movement restriction, difficulty on walking resulting from the pain in legs, absence of muscular weakness, normal muscular tone and normal deep tendon relfexes. Radiological findings have shown ectopic bone in hips, thighs, legs and left shoulder (figure 1).

Division of Child Neurology, Department of Pediatrics, Faculdade de Medicina de Marilia (FMM): * Assistant Professor of Neurology; ${ }^{* *}$ Assistant Professor of Pediatrics; ${ }^{* * *}$ Resident of Pediatrics; ${ }^{* * * *}$ Student of Medicine. Aceite: 23-junho-1993. 


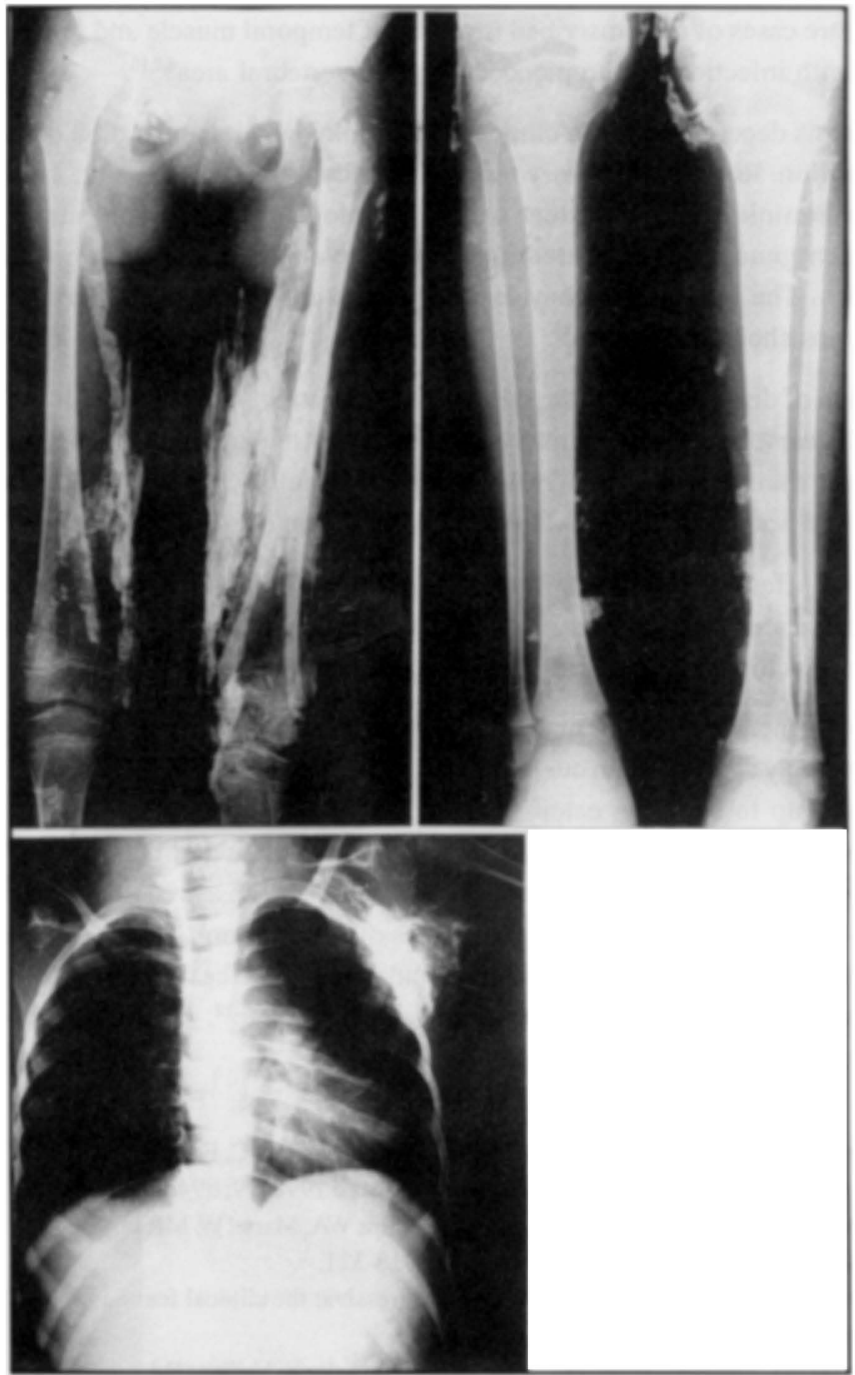

Figure 1. Patient SSM. Radiographs show ectopic bone in: A) hips and thighs; B) legs; C) left shoulder.

Routine laboratory tests were normal. The plasma calcium and inorganic phosphate were normal. The diagnosis was based on clinical and radiological findings. The EHDP, $20 \mathrm{mg} / \mathrm{kg} /$ day, was given to patient.

\section{COMMENTS}

FOP, also known as myositis ossificans progressiva, is a rare autosomal dominant disorder in which there is progressive ectopic ossification and characteristics skeletal malformations ${ }^{8}$. The pathological process suggest that the primary lesion is in the connective tissue around the muscle. There is an exaggerated proliferation of connective tissue with subsequent dystrophic calcification and ossification ${ }^{5}$, but in contrast, Smith et al. state that the muscular tissue is intrinsically abnormal before overgrowth of connective tissue ${ }^{12}$.

Different parts of the body are variably affected by ectopic ossification. Early lesions often occur around the neck and over the back, whereas the most crippling ossification around hip may occur in late or early adult life. Ossification is unusual in smaller muscles and in those of the 
abdomen. There are cases of circumscribed myositis of temporal muscle and femoral region, and a case associated with infection by Streptococcus in paravertebral area ${ }^{4,7,10}$.

The diagnosis depends upon the clinical and radiological demonstration of the characteristic skeletal malformation. Routine laboratory tests are usually normal ${ }^{11}$. Actually, the bone image may be helpful in determining the full extent of the pathological process and more accurated than conventional roentgenographies, detecting lesions even before they can be observed with roentgenographies. The radiographs may lead to understimate the severity of the disease ${ }^{2,6}$. The biopsy of the lumps should be avoided ${ }^{9}$.

Progression of disability is erratic, with severe limitation of movement in spine and shoulder by the age of $\mathbf{1 0}$ years; one or both hips were involved by the age of 20 years and most patients were confined to a chair or to bed with restriction of the joints by the age of 30 years. Progression of the disability did not appear to be influenced by any form of medical treatment ${ }^{3}$.

There is no effective treatment. The management of the patients must be concentrated on the avoidance of exacerbating factors, including trauma of the muscles, biopsies of the lumps, surgeries to excise ectopic bone, intramuscular injections and dental therapy.

Due to our ignorance in this matter, the management of FOP remains empirical; nothing have been outsandingly successful. In our patient, we have used ethane-1-hydroxy-1,1-diphosphonate (EHDP) in an attemp to suppress calcification of the new lesions. The exact mechanism of its action is not known and it is possible that it may have important additional effects on bone cells, either directly or indirectly reducing their activity ${ }^{12}$. Bruni et al. observed a significant improvement in symptoms and recovery of some of the active sites of ossification ${ }^{1}$. Therapeutic progress is likely to be slow while the underlying cause remains unknown, but the advantage of relatively small increase in mobility in these young patients can be considerable ${ }^{12}$.

\section{REFERENCES}

1. Bruni L, Giammaria P, Tozzi MC, Camparcola D, Scopinaro F, Imperato C. Fibrodysplasia ossificans progressiva: an 11-year-old treated with a diphosphonate. Acta Paediatr Scand 1990, 79: 994-998.

2. Caron KH, DiPietro MA, Aisen AM, Heidelberger KP, Phillips WA, Martel W. MR imaging of early fibrodysplasia ossificans progressiva. J Comput Assit Tomogr 1990, 14:318-321.

3. Connor JM, Evans DAP. Fibrodysplasia ossificans progressiva: the clinical features and natural history of 34 patients. J Bone Joint Surg 1982, 64-B: 76-83.

4. Chomette G, Goudot O, Auriol M, Vidal JM, Tranbaloc P, Wechsler B, Vaillant JM, Guilbert F. Myosite ossificante circonscrite faciale: étude anatomo-clinique et tomodensitométrique. Rev Stomatol Chir Maxillofac 1989, 90: 1-6.

5. Eaton WL, Conkling WS, Daeschner CW. Early myositis ossificans progressiva occuring in homozygotic twins: a clinical and pathological study. J Pediatr 1957, 50: 591-598.

6. Guze BH, Schelbert $\mathrm{H}$. The nuclear medicine bone image and myositis ossificans progressiva. Clin Nucl Med 1989, 14: 161-162.

7. Labbe A, Carla $\mathrm{H}$, Mazingue F, Campagne D. Myosite ossificante circonscrite non traumatique de la région fémorale. Pediatrie 1990, 45: 781-784.

8. McKusick VA. Heritable disorders of connective tissue. Ed 4. St. Louis: Mosby 1972, p 687-702.

9. Rogers JG, Geho WB. Fibrodysplasia ossificans progressiva: a survey of forty-two cases. J Bone Joint Surg 1979, 61-A: 909-914.

10. Sijelmassi R, Mallet JF, Ravasse P, Michel C, Delmas P. Myosite ossificante circonscrite rachidienne d'origine infectieuse. Pediatrie 1990, 45: 29-33.

11. Smith R. Myositis ossificans progressiva: a review of current problem. Semin Arthritis Rheum 1975, 4:369380.

12. Smith R, Russel RGG, Woods CG. Myositis ossificans progressiva: clinical features of eight patients and their response to treatment. J Bone Joint Surg 1976, 56-B: 48-57. 